\title{
Nanoparticles as potential new generation broad spectrum antimicrobial agents
}

\author{
Clarence S. Yah ${ }^{1,2^{*}}$ and Geoffrey S. Simate ${ }^{3}$
}

\begin{abstract}
The rapid emergence of antimicrobial resistant strains to conventional antimicrobial agents has complicated and prolonged infection treatment and increased mortality risk globally. Furthermore, some of the conventional antimicrobial agents are unable to cross certain cell membranes thus, restricting treatment of intracellular pathogens. Therefore, the disease-causing-organisms tend to persist in these cells. However, the emergence of nanoparticle (NP) technology has come with the promising broad spectrum NP-antimicrobial agents due to their vast physiochemical and functionalization properties. In fact, NP-antimicrobial agents are able to unlock the restrictions experienced by conventional antimicrobial agents. This review discusses the status quo of NP-antimicrobial agents as potent broad spectrum antimicrobial agents, sterilization and wound healing agents, and sustained inhibitors of intracellular pathogens. Indeed, the perspective of developing potent NP-antimicrobial agents that carry multiple-functionality will revolutionize clinical medicine and play a significant role in alleviating disease burden.
\end{abstract}

\section{Introduction}

In recent past, microbial infections have become a global health burden due to emerging and resistant strains of viruses [1], bacteria [2], pathogenic fungi [3] and protozoa [4] defying clinical treatment. Consequently, this has culminated into prolonged treatment, higher health expenditure, mortality risk, and low life expectancy [2]. In view of ineffective antimicrobial agents, there is need to seek new alternative and safer antimicrobial agents against these "super bugs" of viruses, bacteria, fungi and protozoa. With the development of biomedical nanomaterials, new antimicrobial agents have begun to emerge either as novel and/or augmenting the activities of the current conventional antimicrobials. This is motivated by the vast physiochemical and functionalization (ligand attachment) properties of nanoparticles (NPs) [5-7]. The NPs physiochemical properties are highly diverse in nature and are highly applicable in biomedical field including antimicrobial and drug delivery $[6,8,9]$. Some examples of these biomedical NPs include silver nanoparticles (AgNPs) [10], carbon nanotubes (CNTs) [11],

\footnotetext{
* Correspondence: cyah@nmmu.ac.za

${ }^{1}$ Department of Biochemistry and Microbiology, Nelson Mandela

Metropolitan University, Port Elizabeth, South Africa

${ }^{2}$ Department of Epidemiology, Johns Hopkins Bloomberg School of Public

Health, E7146, 615 N. Wolfe Street, Baltimore 21205, MD, USA

Full list of author information is available at the end of the article
}

gold NPs (AuNPs) [12], zinc oxide NPs (ZnO-NPs) [13], and iron oxide NPs (FeO-NPs) [14].

The antimicrobial actions of NPs include cidal destruction of cell membranes, blockage of enzyme pathways, alterations of microbial cell wall, and nucleic materials pathway [1]. However, the antimicrobial mechanisms of the actions are yet to be fully elucidated since some of the NPs drugs are still at their infancy. The high potency of NPs antiviral, antibacterial, antifungal and antiprotozoal activities may revolutionize and bring another turning point in pharmacological therapy. In that regard, this review looks at the status quo of nanomaterials as alternative antimicrobial agents in terms of their broad spectrum ability, the crossing of difficult membrane barriers, delivery and sustained inhibition of intracellular pathogens and sterilization abilities as shown in Fig. 1. This perspective status quo of NP antimicrobial agents with multiple functions will play a significant impact on the treatment of diseases.

\section{Broad spectrum nanoparticle-antimicrobial agents}

The global emergence of multidrug-resistant microorganisms (viruses, bacteria, fungi and protozoa) has made conventional treatment of infectious diseases difficult. Therefore, the discovery of alternative new classes of antiviral [15], antibiotics [16], antifungal [17], and 


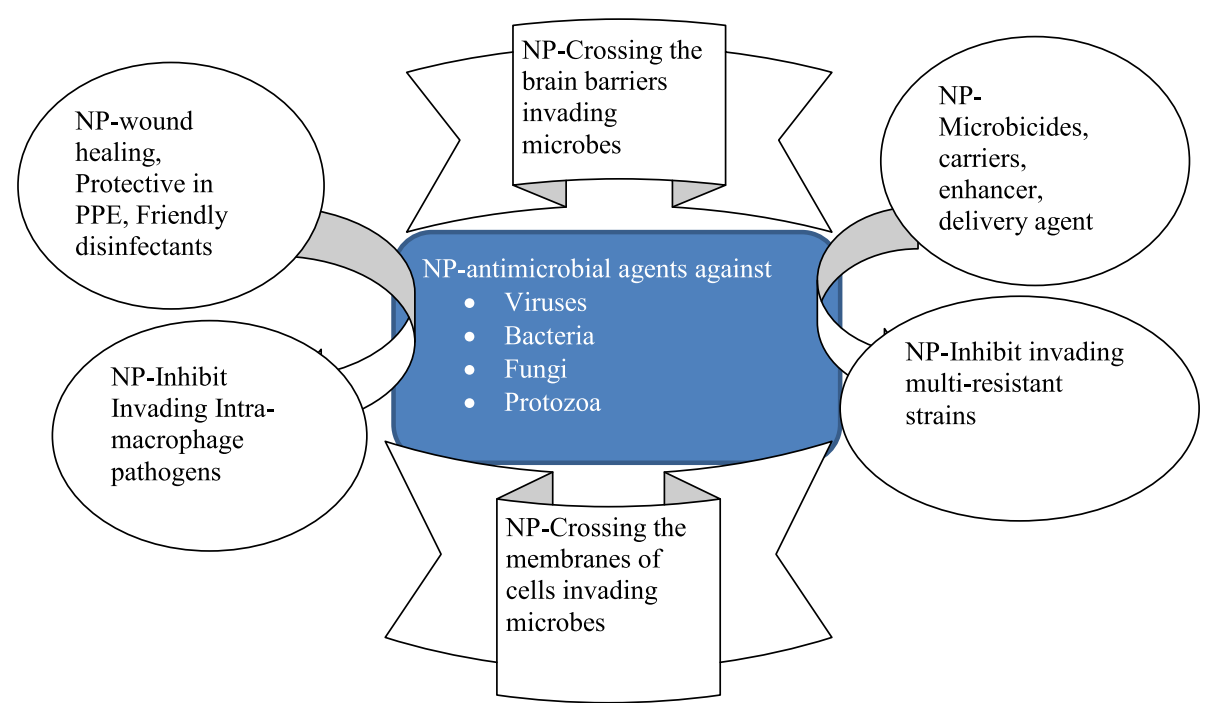

Fig. 1 Multiple functionality and broad spectrum activities of nanoparticles antimicrobial agents. The diverse vast antimicrobial uses of nanoparticle bioconjugates. Used for wound healing, use as anticancers, anti multi-resistant pathogens, aid drugs to cross the blood brain barriers, help in the inhibition of microbes that hide in macrophages. NP = acronyms for Nanoparticles. PPE = Personal Protective equipment incorporated with nanoparticles capable of destroying microbes

antiprotozoal [18] agents that can treat resistant strains is paramount. Research has shown that these emerging broad-spectrum antimicrobial nanomaterial can knockout diverse pathogenic organisms of different phyla, across diverse and/or within species of viruses, bacteria and fungi [19-22]. For example, Fig. 2 shows the broad spectrum NP-antimicrobial effect of AgNPs. The AgNP antimicrobial agent has multi-functionality of antibacterial [22], antifungal [22], antiviral [23], anti-parasitic [4], and anti-inflammatory properties [14, 24].

One of the mechanisms of NP-antimicrobial actions is cell wall lysis. For example, a study by Addae et al. [12] in an attempt to produce a transducer agent for photothermal therapy (PTT) found the destruction of Bacillus

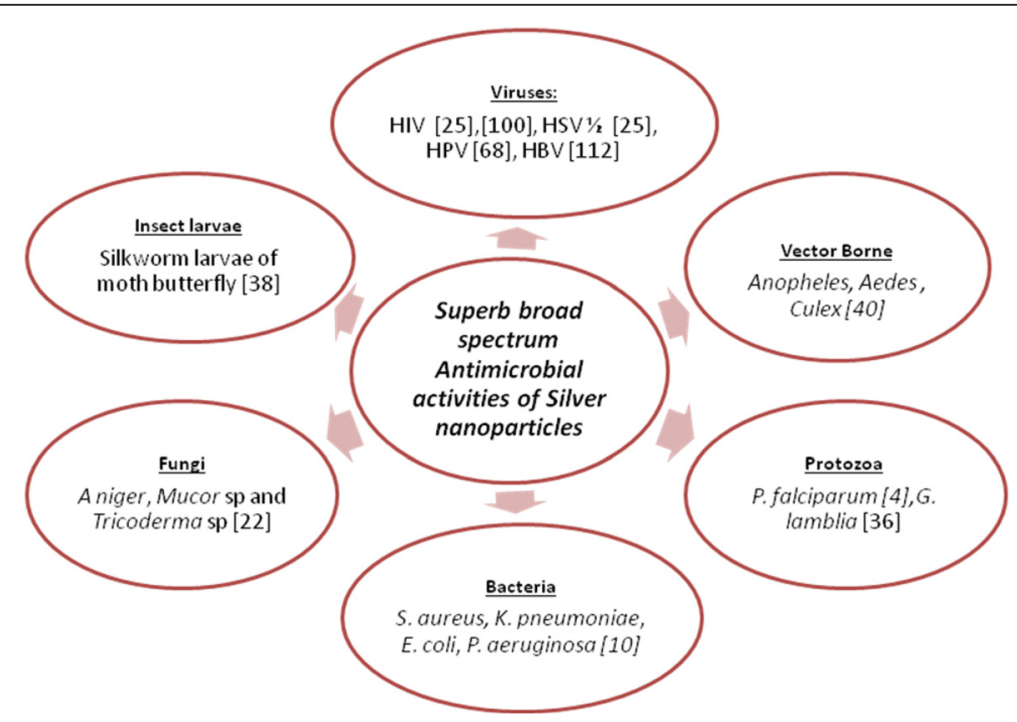

Fig. 2 Broad spectrum NP-antimicrobial activities of silver nanoparticles. The Figure describes the antimicrobial spectrum of silver bio-conjugate nanoparticles against diverse genera of microorganisms. HIV = Human immunodeficiency virus, HSV = Herpes Simplex Virus 1, HPV = Human papillomavirus, HBV = Hepatitis B virus, P. falciparum = Plasmodium falciparum, G. lamblia = Gardia lamblia, S. aureus = Staphylococcus aureus, E. coli $=$ Escherichia coli, P. aeruginosa $=$ Pseudomonas aeruginosa, $\mathrm{sp}=$ species 
species cell membranes when treated with $\mathrm{Au} / \mathrm{CuS}$ NPs. The destruction of Bacillus species in this study proved that $\mathrm{Au} / \mathrm{CuS}$ NPs are potent NP-antimicrobial agents.

The NPs are potential broad spectrum antibiotics because they can inhibit wide range of multidrug-resistant strains of bacteria that have defied most antibiotic treatment. For example, in the study by Adeli et al. [10] it was found that AgNPs were able to inhibit pan-multidrug resistant strains of $S$. aureus, K. pneumoniae, E. coli, and $P$. aeruginosa that were resistant to all the antibiotic drugs including imipenem. Another similar study by Kathiravan et al. [22] showed that AgNPs can inhibit both bacteria ( $S$. aureus, Ecoli, B subtilis) and fungi species (A niger, Mucor sp and Tricoderma sp). In addition, earlier findings by Fayaz et al. [25] showed that the AgNPs-coated condom have antiviral (against HIV-1 and HSV-1/2), antibacterial (against E. coli, S. aureus, M. luteus, K. pneumonia) and anti-fungi (against Candida spp.) properties. This suggests that AgNPs can be used to treat all multi-drug resistant pathogens from diverse phyla from all clinical sources.

The broad spectrum antimicrobial activities have also been demonstrated by CNTs. For example, a study by Tank et al. [26] showed that silica coated silicon nanotubes (SCSNTs) exhibit enhanced antimicrobial activities when compared to other non-silica coated silicon nano-particles. Other studies also found that CNTs containing lysine such as multiwalled CNT (MWCNT)epilsonpolylysine [27], and SWCNT-poly(L-lysine) (PLL), and poly(L-glutamic acid) [28] exhibit very strong broad antimicrobial activities against a wide range of bacteria. A study by Amiri et al. [29] showed MWCNT-lysine exhibiting very strong broad antimicrobial activity against $S$. aureus, S. agalactiae, S. dysgalactiae, E.coli, K. pneumonia and Salmonella typhimurium.

In addition to antimicrobial activities, hybrids of nanomaterials such as cholesterol-containing liposomes phytonanosilver and CNTs have been found to exhibit high antioxidant activity as well as antimicrobial activities against E. coli, Staphylococcus aureus and Enterococcus faecalis [30]. This shows that when two or more NPs are combined, they tend to enhance the broad spectrum activity of the nano-antimicrobial agents. The hydrid behaviour was equally found when CNTs and AgNP-based nanomaterials were combined and the resulting hybrid biocomposite was found to exhibit stronger and excellent antimicrobial properties [27]. Similarly, chitosanCNT hybrid showed excellent antimicrobial activities against bacteria and fungi [9]. Other CNTs antimicrobial hybrids include $\mathrm{ZnO}$ coated MWCNTs (ZnO/MWCNTs) [13], Triad CNT-NPs/Polymer nanocomposites [11], functionalized MWCNTs-CdS and functionalized-MWCNTsAg2S [31], and CdTe QDs/single-walled aluminosilicate nanotubes [32]. Furthermore, Cefalexin-immobilized multi-walled CNTs have been found to broadly enhance the antimicrobial activities against a wide range of pathogens including E. coli, P. aeruginosa, S. aureus and Bacillus subtilis [8] as shown in Table 1 . The combination of AgNPs and CNTs including MWCNT-AgNPs [33] on fiber membrane has also been found to enhance the filtration and antimicrobial potentials against all types of bacteria. In addition, Poly(N-vinylcarbazole) (PVK)-SWCNT nanocomposite coated membrane for water purification were found to destroy all bacterial species including spore forming organisms such as Bacillus subtilis [34]. Apart from filtration and demonstration of antimicrobial activities the MWCNT-AgNPs hybrid composite membrane has been found to significantly reduce biofilm formation which can easily be extended to other types of support membranes [33]. Table 1 summaries the types of NPs and their susceptibility to various organisms.

\section{Nanoparticle anti-parasitic effect}

Despite the efforts made in the treatment of parasitic infections, infections by parasites particularly those of giardiasis, schistosomiasis, trypanosomiasis, malaria, leishmaniasis, dengue fevers, Japanese encephalitis, and filariasis continue to increase particularly in tropical and low income countries $[24,35,36]$. The problems associated with parasitic infections include drug toxicity, ineffectiveness, and developments of resistance to conventional anti-parasitic drugs. Furthermore, treatment costs are high, thus limiting supply of drugs in low income countries [37]. As a results of the limitation in anti-parasitic drugs, newer approaches such as nano-biotechnology have shown significant improvement in the treatment of parasitic infections [24]. This is based on the unique properties of NPs including those of AgNPs, AuNPs, chitosan, selenium oxide, and other metallic oxide based NPs that have shown excellent inhibitory effects against parasitic infections including insect larvae [24, 35-38].

Parasites such as Leishmania can reside and survive inside macrophages without being exposed to cell damage by reactive oxygen species (ROS) and antiparasitic drugs [37]. However, AgNPs, because of their trans-membrane mechanisms and sustained anti-parasitic delivery, can inhibit intracellular Leishmania and enhance their destruction via ROS [37].

Other NPs including the combination of silver, chitosan, and curcumin nanoparticles have been used in the treatment of Giardia lamblia as demonstrated in experimental animals [36]. The findings also showed that Giardia lamblia can be successfully eradicated from stool and intestine [36]. The potential of NPs if fully optimized may lead to the development of newer synergic antimicrobials where two or more nano-antimicrobials are combined to generate an effective efficacy in the 
Table 1 Summary of the types of nanoparticles susceptibility to organisms

\begin{tabular}{|c|c|c|c|c|c|c|}
\hline Type of NP & $\begin{array}{l}\text { Method of NPs } \\
\text { characterization }\end{array}$ & Size of NP & Types organisms inhibited & Outcome & Toxicity & Author \\
\hline Fe-Oxide NP \& AgNP & $\begin{array}{l}\text { UV-vis spectroscopy, } \\
\text { Fourier Transform } \\
\text { Infrared Spectroscopy } \\
\text { (FTIR), Transmission } \\
\text { Electron Microscopy (TEM) }\end{array}$ & $\begin{array}{l}\text { Fe-oxide NP } \\
20-40 \mathrm{~nm} \text {, AgNP } \\
10-20 \mathrm{~nm}\end{array}$ & $\begin{array}{l}\text { Bacillus, E. coli and Staphylococcus } \\
\text { species }\end{array}$ & $\begin{array}{l}\text { Fe-Oxide NPs were sensitive against } \\
\text { Bacillus, E. coli and Staphylococcus } \\
\text { species. }\end{array}$ & $\begin{array}{l}\text { The very smaller size } \\
\text { AgNP were toxic } \\
\text { against the pathogens }\end{array}$ & [14] \\
\hline Ag NPs. & $\begin{array}{l}\text { TEM, Field Emission } \\
\text { Transmission Electron } \\
\text { Microscopy (FESEM), FTIR, } \\
\text { UV-Vis spectra, Raman } \\
\text { spectroscopy, X-ray } \\
\text { Difraction (XRD) }\end{array}$ & Average $18-20 \mathrm{~nm}$ & $\begin{array}{l}\text { Escherichia coli, Pseudomonas spp. } \\
\text { Bacillus species, Staphylococcus } \\
\text { species, Aspergillus niger, Aspergillus } \\
\text { flavus, Penicillium }\end{array}$ & $\begin{array}{l}\text { Inhibited the growth and } \\
\text { multiplication of E. coli, Pseudomonas } \\
\text { species, Bacillus spp. and } \\
\text { Staphylococcus species, A. niger, A. } \\
\text { flavus, Penicillium spp }\end{array}$ & ND & [98] \\
\hline $\begin{array}{l}\text { Silver, chitosan, } \\
\text { and curcumin } \\
\text { nanoparticles }\end{array}$ & NA & - & Giardia lamblia & $\begin{array}{l}\text { The highest effect was achieved by } \\
\text { combining the three nanoforms. The } \\
\text { parasite was found to be eradicated } \\
\text { from stool and intestine. }\end{array}$ & $\begin{array}{l}\text { None of the } \\
\text { nanoparticle exhibited } \\
\text { toxic effect }\end{array}$ & [36] \\
\hline AgNPs & UV spectra, TEM & $\begin{array}{l}2-30 \mathrm{~nm} \text {; averagely } \\
20 \mathrm{~nm}\end{array}$ & $\begin{array}{l}\text { S. aureus, Klebsiella pneumoniae, } \\
\text { Escherichia coli, and Pseudomonas } \\
\text { aeruginosa }\end{array}$ & $\begin{array}{l}\text { The AgNPs produced had strong } \\
\text { antibacterial effect against all the } \\
\text { pathogenic bacteria }\end{array}$ & ND & {$[10]$} \\
\hline $\begin{array}{l}\text { polyvinylpyrrolidone } \\
\text { (PVP)-coated silver } \\
\text { nanoparticles }\end{array}$ & - & $1-10 \mathrm{~nm}$ & HIV-1 & $\begin{array}{l}\text { PVP-coated AgNP exhibit potent } \\
\text { cyto-protective and post-infected } \\
\text { anti-HIV-1 activities toward } \\
\text { Hut/CCR5 cells. }\end{array}$ & ND & [99] \\
\hline $\begin{array}{l}\text { PVP-coated silver } \\
\text { nanoparticles }\end{array}$ & - & $30-50 \mathrm{~nm}$ & HIV-1 & $\begin{array}{l}\text { PVP-coated AgNPs Inhibited cell- } \\
\text { associated HIV-1 and cell-free HIV-1 } \\
\text { transmission. }\end{array}$ & $\begin{array}{l}\text { PVP-coated AgNPs were } \\
\text { non toxic to cells } \\
\text { explant }\end{array}$ & {$[100]$} \\
\hline $\begin{array}{l}\text { mercaptoethane sulfonate } \\
\text { (MES)-coated silver and } \\
\text { gold nanoparticles }\end{array}$ & - & $4 \mathrm{~nm}$ & Herpes simplex virus type 1 (HSV-1) & $\begin{array}{l}\text { The MES-coated silver and gold } \\
\text { nanoparticles inhibited HSV-1 infec } \\
\text { tion in cell culture }\end{array}$ & $\begin{array}{l}\text { The MES-coated silver } \\
\text { and gold were non } \\
\text { toxic to host cells }\end{array}$ & {$[101]$} \\
\hline PVP-coated silver nanoparticles & - & $69 \mathrm{~nm}+/-3 \mathrm{~nm}$ & Respiratory syncytial virus (RSV) & Inhibited RSV infection & $\begin{array}{l}\text { showed low toxicity to } \\
\text { cells }\end{array}$ & {$[102]$} \\
\hline $\begin{array}{l}\text { AgNP and } \\
\text { polysaccharide- } \\
\text { coated AgNP }\end{array}$ & - & $10-80 \mathrm{~nm}$ & Monkey pox virus (MPV) & $\begin{array}{l}\text { The AgNPs of approximately } 10 \mathrm{~nm} \\
\text { inhibit MPV infection in vitro, as an } \\
\text { anti-viral }\end{array}$ & $\begin{array}{l}\text { Non of te GgNPs were } \\
\text { cytotoxic (Vero cell } \\
\text { monolayer sloughing) }\end{array}$ & {$[103]$} \\
\hline AgNPs & - & $10-50 \mathrm{~nm}$ & Hepatitis B virus (HBV) & $\begin{array}{l}\text { AgNPs inhibited in vitro HBV RNA } \\
\text { and extracellular virions }\end{array}$ & ND & {$[104]$} \\
\hline $\begin{array}{l}\text { AgNPs and } \\
\text { polysaccharide- } \\
\text { coated AgNP }\end{array}$ & - & $10 \mathrm{~nm}$ & Tacaribe virus (TCRV) & $\begin{array}{l}\text { AgNPs inhibited the TCRV infection } \\
\text { in vitro }\end{array}$ & ND & {$[105]$} \\
\hline Ag-NPs-coated PUC & $\begin{array}{l}\text { High resolution Scanning } \\
\text { Electron Microscopy } \\
\text { (HrSEM), UV Spectra }\end{array}$ & $30-60 \mathrm{~nm}$ & $\begin{array}{l}\text { E. coli, S. aureus, M. luteus, K. pneumoniae, } \\
\text { and Candida tropicalis, Candida krusei, } \\
\text { Candida glabrata, and Candida albicans } \\
\text { and HIV-1 }\end{array}$ & $\begin{array}{l}\text { Ag-NPs-coated PUC with HIV-1 and } \\
\text { HSV- } 1 / 2 \text { was able to inactivate their } \\
\text { infectiousness as well as bacterial } \\
\text { and fungal species }\end{array}$ & ND & {$[25]$} \\
\hline
\end{tabular}


Table 1 Summary of the types of nanoparticles susceptibility to organisms (Continued)

\begin{tabular}{|c|c|c|c|c|c|c|}
\hline $\begin{array}{l}\text { Mycosynthesized silver } \\
\text { nanoparticles }\end{array}$ & $\begin{array}{l}\text { UV spectra, TEM, } \\
\text { Nanosight-LM 20; }\end{array}$ & $4-46 \mathrm{~nm}$ & $\begin{array}{l}\text { HSV } 1 \text { and } 2 \text { and with human } \\
\text { parainfluenza virus type } 3 \text {. }\end{array}$ & $\begin{array}{l}\text { Smaller-sized AgNPs were able to } \\
\text { inhibit the infectivity of the viruses }\end{array}$ & ND & [23] \\
\hline AgNPs & $\begin{array}{l}\text { UV-vis spectroscopy, SEM, } \\
\text { TEM, FTIR and XRD. }\end{array}$ & $\begin{array}{l}18 \text { to } 45 \mathrm{~nm} \text { with an } \\
\text { average size of } \\
32 \mathrm{~nm}\end{array}$ & $\begin{array}{l}\text { Anopheles stephensi, Aedes } \\
\text { aegypti, and Culex quinquefasciatus }\end{array}$ & $\begin{array}{l}\text { AgNPs showed biolarvicidal effect to } \\
\text { A. stephensi, A. aegypti, and C. } \\
\text { quinquefasciatus. }\end{array}$ & ND & [39] \\
\hline AgNPs & $\begin{array}{l}\text { UV-vis spectroscopy, SEM, } \\
\text { FTIR and XRD. }\end{array}$ & $41-60 \mathrm{~nm}$. & $\begin{array}{l}\text { Anopheles stephensi, Aedes aegypti, } \\
\text { and Culex quinquefasciatus }\end{array}$ & $\begin{array}{l}\text { The AgNPs were effective in } \\
\text { destroying the vectors of mosquito } \\
\text { vector blood born parasites }\end{array}$ & ND & {$[40]$} \\
\hline AgNPs & $\begin{array}{l}\text { Atomic force microscopy } \\
\text { (AFM), UV-vis } \\
\text { spectroscopy, FTIR }\end{array}$ & $60-95 \mathrm{~nm}$ & $\begin{array}{l}3 \text { instar larvae of Culex } \\
\text { quinquefasciatus }\end{array}$ & $\begin{array}{l}\text { AgNPs exhibited high mortality } \\
\text { against larvae of Culex } \\
\text { quinquefasciatus }\end{array}$ & ND & {$[78]$} \\
\hline AgNPs & $\begin{array}{l}\text { UV-vis spectroscopy, SEM, } \\
\text { energy-dispersive X-ray } \\
\text { (EDX) spectroscopy. }\end{array}$ & 43.52 to $142.97 \mathrm{~nm}$ & Aedes aegypti & $\begin{array}{l}\text { The Bt-AgNPs showed larvicide ef } \\
\text { fect against mosquito larva A. } \\
\text { aegypti }\end{array}$ & ND & [106] \\
\hline $\begin{array}{l}\text { Polyvinyl-N-carbazole (PVK) and } \\
\text { single-walled carbon nanotubes } \\
\text { (SWNTs) (PVK:SWNT) }\end{array}$ & UV vis spectra, FTIR, SEM & NA & E. coli MG 1655 and B. subtilis-102 & $\begin{array}{l}\text { The nano-composite showed anti } \\
\text { microbial activity against both } \\
\text { Gram-positive and negative } \\
\text { bacterial isolates. }\end{array}$ & $\begin{array}{l}\text { The PVK-SWNT were } \\
\text { non toxic to fibroblast } \\
\text { cells }\end{array}$ & {$[34]$} \\
\hline MWCNT-Iysine functionalized & $\begin{array}{l}\text { FTIR, Thermal gravimetric } \\
\text { analysis (TGA), Raman } \\
\text { spectra and TEM }\end{array}$ & N/A & $\begin{array}{l}\text { S. aureus, Streptococcus agalactiae, S. } \\
\text { dysgalactiae, E. coli, K. pneumonia, S. } \\
\text { typhimurium }\end{array}$ & $\begin{array}{l}\text { The functionalized MWCNT with } \\
\text { lysine expressed high antimicrobial } \\
\text { effect against all bacterial cells }\end{array}$ & ND & [29] \\
\hline MWCNT-AgNPs & $\begin{array}{l}\text { Inductively coupled } \\
\text { plasma atomic emission } \\
\text { spectroscopy (ICP-AES), } \\
\text { XRD, FTIR }\end{array}$ & 3 to $30 \mathrm{~nm}$ & Escherichia coli & $\begin{array}{l}\text { MWCNT-AgNPs exhibited strong } \\
\text { antimicrobial activities and reduce } \\
\text { biofilm formation. }\end{array}$ & ND & [33] \\
\hline $\begin{array}{l}\text { Silicon nanotubes (SNTs), } \\
\text { silicon nanoparticles (SNPs) }\end{array}$ & $\begin{array}{l}\text { SEM-EDX, TEM, Brunauer- } \\
\text { Emmett-Teller (BET), STM, } \\
\text { Raman spectroscopy. }\end{array}$ & $\begin{array}{l}\text { average diameter of } \\
14\end{array}$ & $\begin{array}{l}\text { Multidrug-resistant Staphylococcus } \\
\text { aureus }\end{array}$ & $\begin{array}{l}\text { SCSNTs were effective in limiting } \\
\text { the growth of multidrug-resistant } \\
S \text { aureus }\end{array}$ & ND & {$[26]$} \\
\hline $\mathrm{Ag}-\mathrm{Fe} / \mathrm{SWCNTs}$ & $\begin{array}{l}\text { TEM, SEM, XRD, Raman } \\
\text { spectra }\end{array}$ & $\begin{array}{l}1-10 \mathrm{~nm} \text { Ag-Fe NP } \\
\text { dispersed and tightly } \\
\text { attached to the outer } \\
\text { surfaces of SWCNTs }\end{array}$ & Escherichia coli. & $\begin{array}{l}\text { Purified } \mathrm{Ag}-\mathrm{Fe} / \mathrm{SWCNT} \text { hybrid } \\
\text { nanoparticles were effective } \\
\text { against } E \text {. coli. }\end{array}$ & ND & [104] \\
\hline $\begin{array}{l}\text { SWCNTs combine with } \mathrm{H}_{2} \mathrm{O}_{2} \text { or } \\
\mathrm{NaOCl}\end{array}$ & TEM, SEM-EDX & SWCNTs $1-1.5 \mathrm{~nm}$ & Bacillus anthracis Spores & $\begin{array}{l}\text { The combined effect of SWCNTs } \\
\text { and } \mathrm{H}_{2} \mathrm{O}_{2} \text { or } \mathrm{NaOCl} \text { exhibited } \\
\text { sporicidal effect on } B \text {. anthracis } \\
\text { spores }\end{array}$ & ND & {$[87]$} \\
\hline SWNT/PLL/PGA & $\begin{array}{l}\text { Uv spectra, TEM, SEM, } \\
\text { Quartz crystal } \\
\text { microgravimetry }\end{array}$ & SWNT is $0.8-1.2 \mathrm{~nm}$ & E. coli and S. epidermidis & $\begin{array}{l}\text { SWNT/PLL/PGA highly inactivated } \\
\text { E. coli and S. epidermidis }\end{array}$ & ND & {$[28]$} \\
\hline Zirconia (ZrO2) nanoparticles & $\begin{array}{l}\text { SEM, EDX, AFM, U vis } \\
\text { spectra, FTIR }\end{array}$ & $\begin{array}{l}50 \mathrm{e} 100 \mathrm{~nm} \text {, average } \\
\text { size } 50 \mathrm{~nm}\end{array}$ & $\begin{array}{l}\text { Staphylococcus aureus, Escherichia coli, } \\
\text { Candida albicans, Aspergillus niger }\end{array}$ & $\begin{array}{l}\text { Zirconia ( } \mathrm{ZrO} 2) \text { nanoparticles } \\
\text { exhibited antifungal and } \\
\text { antibacterial against the test } \\
\text { organisms. }\end{array}$ & ND & [111] \\
\hline
\end{tabular}


Table 1 Summary of the types of nanoparticles susceptibility to organisms (Continued)

\begin{tabular}{|c|c|c|c|c|c|c|}
\hline $\begin{array}{l}\text { Au/CuS core/shell nanoparticles } \\
\text { (NPs) }\end{array}$ & $\begin{array}{l}\text { HRTEM, SEM, energy } \\
\text { dispersive X-ray } \\
\text { spectroscopy (EDS) }\end{array}$ & $2-5 \mathrm{~nm}$ & B. anthracis spores and cells & $\begin{array}{l}\text { The Au/CuS NPs were highly } \\
\text { efficient in inactivating B. anthracis } \\
\text { cells, but not effective to the spores. }\end{array}$ & ND & [12] \\
\hline $\begin{array}{l}\text { Sialic-acid functionalized gold } \\
\text { nanoparticles }\end{array}$ & TEM & $2 \mathrm{~nm}$ and $14 \mathrm{~nm}$ & Influenza virus & $\begin{array}{l}\text { The NPs inhibition influenza virus } \\
\text { infection }\end{array}$ & $\begin{array}{l}\text { The functionalized } \\
\text { AuNPs were nontoxic } \\
\text { to the cells }\end{array}$ & [107] \\
\hline $\begin{array}{l}\text { Titanium dioxide nanoparticles } \\
\text { (TiO2 NPs) }\end{array}$ & XRD, FTIR, SEM, EDX, AFM. & $\begin{array}{l}\text { Average size of } \\
70 \mathrm{~nm} \text {. }\end{array}$ & $\begin{array}{l}\text { Pediculus humanus capitis De Geer } \\
\text { (Phthiraptera: Pediculidae); larvae of } \\
\text { cattle tick Hyalomma anatolicum (a.) } \\
\text { anatolicum Koch (Acari: Ixodidae), and } \\
\text { fourth instar larvae of malaria vector } \\
\text { Anopheles subpictus Grassi (Diptera: } \\
\text { Culicidae). }\end{array}$ & $\begin{array}{l}\text { The } \mathrm{TiO}_{2} \mathrm{NPs} \text { showed significant } \\
\text { mortality against the vectors borne } \\
\text { organisms }\end{array}$ & ND & \\
\hline $\begin{array}{l}\text { Chrysosporium tropicum } \\
\text { mediated silver and gold } \\
\text { nanoparticles }\end{array}$ & $\begin{array}{l}\text { Microscan reader, XRD, } \\
\text { TEM, SEM }\end{array}$ & $\begin{array}{l}\text { AuNPs: } 2-15 \mathrm{~nm} \text { and } \\
\text { AgNP: } 20-50 \mathrm{~nm}\end{array}$ & Aedes aegypti larvae. & $\begin{array}{l}\text { The AuNPs used as an efficacy } \\
\text { enhancer shown mortality } 3 \text { times } \\
\text { higher Aedes aegypti larvae. }\end{array}$ & ND & {$[41]$} \\
\hline $\begin{array}{l}\text { Zinc oxide nanoparticles } \\
\text { (ZnO NPs) }\end{array}$ & $\begin{array}{l}\text { UV-visible spectroscopy, } \\
\text { XRD, FTIR, SEM }\end{array}$ & $60-120 \mathrm{~nm}$. & $\begin{array}{l}\text { larvae of cattle tick Rhipicephalus } \\
\text { (Boophilus) microplus, Canestrini } \\
\text { (Acari: Ixodidae); head louse Pediculus } \\
\text { humanus capitis, De Geer (Phthiraptera: } \\
\text { Pediculidae); larvae of malaria vector, } \\
\text { Anopheles subpictus, Grassi; and filariasis } \\
\text { vector, Culex quinquefasciatus, Say } \\
\text { (Diptera: Culicidae). R. microplus larvae }\end{array}$ & $\begin{array}{l}\text { The ZnO NPs had significant } \\
\text { inhibitory effect on the parasites }\end{array}$ & ND & [110] \\
\hline Cobalt nanoparticles (CoNPs) & $\begin{array}{l}\text { XRD, FTIR FESEM with } \\
\text { energy dispersive X-ray } \\
\text { spectroscopy, and TEM }\end{array}$ & $\begin{array}{l}\text { average size of } \\
84.81 \mathrm{~nm} \text {. }\end{array}$ & $\begin{array}{l}\text { malaria vector Anopheles subpictus and } \\
\text { dengue vector Aedes aegypti (Diptera: } \\
\text { Culicidae). }\end{array}$ & $\begin{array}{l}\text { The larvicidal effect was observed } \\
\text { in the cobalt acetate solution } \\
\text { and against the A. subpictus } \\
\text { and A. aegypti }\end{array}$ & ND & {$[108]$} \\
\hline $\begin{array}{l}\text { Copper(II) nanohybrid solids, } \\
\mathrm{LCu}\left(\mathrm{CH}_{3} \mathrm{COO}\right)_{2} \text { and } \mathrm{LCuCl}_{2}\end{array}$ & $\begin{array}{l}\text { TEM, dynamic light } \\
\text { scattering, and IR } \\
\text { spectroscopy }\end{array}$ & $\begin{array}{l}5-10 \text { and } 60-70 \mathrm{~nm} \\
\text { of } \mathrm{LCu}\left(\mathrm{CH}_{3} \mathrm{COO}\right)_{2} \\
\text { and } \mathrm{LCuCl}\end{array}$ & Plasmodium falciparum (MRC 2). & $\begin{array}{l}\text { The two compounds showed } \\
\text { significant antimalarial activities } \\
\text { against the parasites }\end{array}$ & $\begin{array}{l}\text { The copper(II) } \\
\text { nanohybrid solids } \\
\text { were nontoxic to } \\
\text { human hepatocellular } \\
\text { carcinoma cells }\end{array}$ & [109] \\
\hline
\end{tabular}


eradication and probably the elimination of parasitic infections. Some studies have shown that modified Plasmodium berghei sporozoite (Tg-Pb/PfCSP) and self-assembling protein NP (SAPN) vaccine presenting Plasmodium falciparum circumsporozoite protein epitopes (PfCSP-SAPN) can stimulate humoral and cellular responses against Plasmodium falciparum using the complement classical pathway cascade [4]. The results indicates the potential application of the circumsporozoite protein epitopes (PfCSP-SAPN) in the development of protective effector memory CD8+ T-cells [4] capable of generating strong long-lived IgG.

\section{Nanoparticle anti-vector borne diseases}

As a result of the increase in the prevalence of vector borne diseases, the production of environmentally friendly and safe NP insecticides synthesized from plants are currently available. These include those of AgNPs synthesized from the leaf extracts of Heliotropium indicum [39], and Azadirachta indica [40]. These insecticides have shown maximum efficacy against blood feeding mosquitoes of Anopheles stephensi, Aedes aegypti, and Culex quinquefasciatus $[39,40]$. This shows that eco-friendly NPs have the potential of controlling vector transmitted infections that have significantly contributed to disease burden, social debility, poverty and death in mostly low income countries $[39,40]$. However, due to NPs non-specific actions to environmental organisms, this may deter their usefulness as vector control agents [40-42].

\section{Wound healing and nanoparticles}

Wound dressing and wound healing are very important components of reducing morbidity and mortality of wound related burden. A wound is a debilitated tissue that results from a breakdown in the skin giving rise to a physiological condition for microbial manifestation including opportunistic pathogens [43, 44] affecting wound healing [45]. Depending on the degree of wound, whether acute or chronic, wound care is necessary to reduce infection or abnormal bacterial presence that may cause stress and other health consequences $[44,46]$. Over the years, wound dressing and healing have been problematic to clinicians [46]. Because there is no single appropriate wound dressing material that can act as a potent sterile antimicrobial agent capable of absorbing excess exudate, preserving the wound from external sources of infection, preventing excess heat at the wound, impermeable to gases, and a dressing that is easy to remove without further trauma to the wound [47] has complicated wound healing. Wound dressing materials such as gauze are associated with painful removal and may cause trauma and associated stress [48].

Nevertheless, the research on NPs in wound dressing materials has come at an opportune time. The NP wound dressing materials provide biocompatible antimicrobial agents that are inexpensive, soft, and flexible, and conform to the contours of the body $[49,50]$. For example, AgNPs wound dressing antimicrobial nanomaterials have been introduced to supplement traditional wound dressing because the slow release of the AgNPs allow the dressing to be changed less frequently, but is highly effective and efficient in wound healing with less antimicrobial resistance [49]. Furthermore, a study by Guidelli et al. [51] showed that natural latex rubber blended with AgNPs gradually released the AgNPs, but was useful in promoting and facilitating wound healing as well as the reduction in scar formation [49]. The AgNPs may also mediate wound healing via reduced mitochondria activity that does not affect the host cell viability with rapid re-establishment of the body integrity [52]. According to a study by Tian et al. [53] AgNPs exert positive broad spectrum antimicrobial properties by reducing wound inflammation, and modulation of fibrogenic cytokines.

Similarly, other findings by John and Moro [54] showed that NPs hydrogel wound dressing consist of methacrylate backbone and terminal hydroxyl group capable of providing versatile and excellent wound healing. This is because the NPs hydrogel dressing powders have thermal insulators capable of absorbing some of the blood or wound exudate, thus providing an impermeable potent antimicrobial environment to wound pathogens as well as protecting the wound from external contamination [50,54]. The NPs hydrogel are cost effective, user friendly, easy to apply, do not adhere to the wound and have minimal need for secondary dressing [54].

Apart from AgNPs, other NPs equally used in wound healings include those of gold [55], curcuminencapsulated NPs [56], chitin/nanosilver composite with good blood clotting ability [57], conjugated iron oxide NPs [58], and nitric oxide releasing NPs [59]. However, the significant acceleration of wound healing by nanomaterials still remains a mystery and the mechanisms of action are still to be fully elucidated and unfold.

\section{Nanoparticles microbicides activities}

With the increase in sexually transmitted infections (STI) fuelling the HIV burden and other health problems, microbicides may be considered as alternative preventive methods of STI and HIV [60, 61]. Microbicides are antimicrobial agents that are self-applied on the vagina or rectum to protect against STIs $[19,62,63]$. Hence they act as chemical, biological and/or physical barriers that prevent transmission of pathogens during sexual intercourse [62, 64, 65]. They may be in gel, creams, rings, or films form and can be used with condoms, thus offering additional protection or used alone especially by those who do not appreciate the use of 
condoms [19]. The microbicides may be used by both HIV positive and heathy individuals to prevent transmission of the virus. Studies have shown that microbicides may provide prevention against HIV and STI infections for those practicing receptive anal and/or vaginal intercourse [63]. In addition, microbicides can provide individuals with protection especially those who are unaware of their partner HIV status including those on antiretroviral therapies (ART) and undetectable HIV viral load [63].

Research studies have shown that NPs-microbicides including those of dendrimer-nanoscale-microbicides hold potential safety efficacy against viruses [19, 66-68]. For example, the VivaGel ${ }^{\mathrm{Tm}}$ (SPL7013Gel) dendrimer is carefully formulated against HIV and HSV and does not interfere with vaginal or rectal physiological $\mathrm{pH}[19,69]$. The dendrimer VivaGe ${ }^{\mathrm{Tm}}$ microbicide is meant to disrupt and block viral attachment and/or prevent the viral adsorption from targeting cells of the rectum or vagina. In the case of HIV the gp120 of the virus are blocked from attaching to the CD4 receptors of human white blood cells [19]. In a study by Chonco et al. [60], it was found that carbosilane dendrimer microbicide are capable of exhibiting HIV thus blocking potential in epithelial monolayer in vitro model cells. Other dendrimers such as heparan sulfate-binding peptide were found to inhibit human papillomaviruses [68] thus, acting as promising antiviral microbicides.

\section{Nanoparticles inhibition of intra-macrophage pathogens}

Pathogenic organisms that traverse cell membranes or reside in nerve cells cause persistence infections and, thus are difficult to treat [70]. Bacteria such as Brucella, Mycobacterium, Listeria species and viruses including HIV, and herpes simplex are intracellular pathogens that invade treatment and persistently exhibit latent infections [70-72]. Therefore, some drugs find it difficult to reach such cells, thus complicating the elimination and eradication of such microbial pathogens [73]. Some of the pathogens may invade cells and exist as intramacrophage pathogens and central nervous infections escaping drugs action as well as immunological responses [71, 73]. Health care workers (HCWs) find it very difficult and frustrating when providing treatment to such intravascular disease causing pathogens due to failure of conventional antimicrobial drugs to destroy such organisms. Drugs for treating such diseases including HIV, encephalopathy and cerebrovascular infections may not lack potency, but due to shortcomings of poor or inefficient intracellular penetration and sustained drugs concentration, may limit treatment efficiency and efficacy [73]. The problems associated with such drugs may include lack of solubility and bio-distribution to reach target areas, thus do not have sufficient drug delivery profile.

Nano-drugs such as polymeric NPs, dendrimers, polymer micelles, and solid lipid NPs have been shown to exhibit excellent antimicrobial profiles and have potent ligand conjugates that improve the pharmacological and therapeutic profile of such drugs to cross such cell membranes, internalize and render efficient antimicrobial potentials $[70,71,73]$. The delivery process provide NPdrugs with multiple functions of carrier, delivery, and antimicrobial capabilities $[71,73,74]$. These attributes are due to the small size $(1-100 \mathrm{~nm})$, vast NPs-functionalization ability, and the robust physiochemical properties, even if biodegradability and the toxicological challenges may be hindering beneficial health outcomes $[75,76]$.

As mentioned earlier, organisms such Brucella species, Mycobacterium tuberculosis exist as intra-macrophage pathogen rendering standard treatment very difficult [71, 72]. For example, Brucella species usually invade, reside and survive within phagocytic, dendritic and trophoblast cells, thus making treatment potential very difficult to clinicians [71]. Similarly, Mycobacterium tuberculosis bacteria responsible for tuberculosis reside inside macrophage resulting into persistent tuberculosis [77]. The same effect has been demonstrated by herpes simplex virus that hides and resides in nerve cells causing latent herpes zosters infections [78]. The use of NPs could be beneficial for such treatments because of the NPs antimicrobials potentials, ease membrane crossing ability and delivery potentials of materials into such cells. They play the role of carrier, delivery and sustain antimicrobials effect in such cells. For example, AgNPs have huge biocidal effect and have been shown to cross the macrophage cell wall and inhibit intra-macrophage Bacillus abortus; a maternal bacterium that tend to resist treatment and causes perinatal morbidity during pregnancy [79].

Furthermore, some pathogens are highly resistant to extreme temperatures and difficult to be eliminated by antibiotics or other chemicals. Nanomaterials and other emerging materials have been reported to be potent antimicrobial agents capable of destroying such pathogens that are tolerant to extreme temperatures and resistant to treat with conventional antibiotics [80]. For example, SWCNTs coupled within 20 minutes near infrared (NIR) treatment significantly increases the potential effect of antimicrobials against Bacillus anthracis spores when compared to non NIR treated SWCNTs [67]. In addition, a study by Martínez-Gutierrez et al. [81] found that $24 \mathrm{~nm}$ AgNPs were not only potent antibacterial agents against resistant strains of bacteria, but also had anti-coagulation activities as well as inflammatory response in macrophages. This indicates that nanomaterials can easily be modified as efficient intravascular 
agent for the destruction of intravascular pathogens as well as delivery agents since they are capable of crossing membrane cell walls without any cell damage or harm [82]. However, the mechanisms of cell membrane or pathways used by the NPs antimicrobial agents in crossing/cell uptake are still to be fully explained [82].

\section{Nanoparticles penetration of the brain barriers and difficult to reach tissues or cells}

Infections of the brain are often very difficult to treat because of the difficulty of most antimicrobial agents to cross the blood brain barrier and inhibit microbial agents [84]. This is due to the fact that the brain is made up of complex cell networks that filter foreign materials, protect and prevent the brain from injuries and diseases [83]. However, some small microbes such as viruses as well as some bacteria are still capable of bypassing and crossing the blood brain barrier [83, 84]. Substances entering the brain are mediated through a tight regulated systematic process of membrane transporters [82-84]. This tight regulatory system prevents most pharmacological antimicrobial agents from crossing the blood brain barrier and exercising their pharmacological activities [82-84]. In this regard nanotechnological antimicrobial agents could bring a novel dimensional approach that is capable of overcoming and bypassing the complex brain cell network, and inhibiting the brain pathogens, thus reducing the burden of microbial brain infections [85]. The NPs can potentially carry and potentially deliver antimicrobial across the blood brain barrier. In fact, it is known that NPs have very small nanosizes that exhibit vast physiochemical multifunctional properties that play a significant role of crossing the blood brain barrier with ease. These features of being able to transiting difficult biological system with ease without disrupting or damaging the cell membranes and sustaining the antimicrobials have made NPs and/or nanomaterials (nano-functionalizedligands) very attractive for biomedical applications [5, 86]. For example, a single oral administration of polylactide-co-glycolide NP-encapsulated antituberculosis drugs consisting of rifampicin + isoniazid + pyrazinamide + ethambutol conjugate in murine mice was found to cross the blood brain barrier and sustained for 9 days in the brain [86]. Furthermore, based on colony forming unit enumerations and pathological examinations, the study showed that 5 oral doses administered every 10th day improved the pharmacologic activities of the polymer NP-antituberculosis drugs resulting in an undetectable level of Mycobacterium tuberculosis in the mice meninges [86].

The mechanisms of action of how the polymer- antituberculosis nanomaterials bypassed the complex cell network of blood brain barriers are yet to be uncovered. It is envisaged that the development of emerging novel NP-antimicrobial agents will soon revolutionize clinical medicine [86]. It is anticipated that the crossing of the blood brain barrier by NP-antimicrobial agents including other classes of drugs would reduce the burden of infections including meningitis caused by vast majority of pathogens.

\section{Nanoparticles enhancement of antimicrobial activities of other agents}

The NPs play a significant role in enhancing the activities of other agents leading to effective and efficient treatment action. For example, the combination of SWCNTs and hydrogen peroxide $\left(\mathrm{H}_{2} \mathrm{O}_{2}\right)$ or $\mathrm{NaOCl}$ increases the sporicidal effect on the spores of organisms such as Bacillus species when compared to treatment with $\mathrm{H}_{2} \mathrm{O}_{2}$ or $\mathrm{NaOCl}$ alone at the same concentrations [87]. In such treatments, synergistic mechanisms of efficacy are established due to contribution of multiple antimicrobial effects. Further analysis shows that SWCNTs do not only play the role of antimicrobial effect, but also increases permeability/susceptibility of the Bacillus species pathogen to $\mathrm{H}_{2} \mathrm{O}_{2}$ or $\mathrm{NaOCl}$, thus significantly developing high effective sporicidal effect [87]. Furthermore, findings by Gilbertson et al. [6] found that oxygen functional groups when functionalized on MWCNTs, enhances several MWCNT properties such as redox activity, electrochemical and antimicrobial activities. The redox activities include the ability to enhance the oxidation of glutathione, and the reduction of surface carboxyl groups that promote the functional performance of MWCNTs antimicrobial activities for biomedical application [6]. This synergetic effect has equally been shown by AgNPs which enhanced the angiogenic properties of natural latex rubber for cell growth and wound healing [51].

\section{Nanoparticles disinfectants}

The inventive approach of nanomaterials as disinfectant relate to their stability, homogeneity, high efficiency and efficacy of broad biocide spectrum of virucidal, bactericidal, fungicidal, antiparasitic and sporicidal as well as mycobactericidal and mycoplasmicidal potentials [88-90]. These excellent disinfectant properties as well as the additional ability of NPs surface functionalization and the dispersion on the NPs surfaces have been exhibited by a wide range of NPs [5-7]. Such functional groups provide very potent additional antimicrobial properties and include ligands such as hydroxyl, carboxyl, amine, and other chemical radicals [5]. The NPs including those of silver, copper and gold [91] have excellent cleaning and disinfecting properties. Some of these NPs are now being used as cleaning disinfectants in hospitals. In such instances, the surfaces may be coated with potent nanomaterials against nosocomial pathogens including the stubborn multi-drug resistant pathogens of Methicillin-resistant Staphylococcus aureus 
(MRSA) that are responsible for most nosocomial infections [88, 92]. For example, silicone polymers of AuNPs have shown to actively reduce the microbial load on clinical surfaces, particularly, when the surfaces are activated with white light [93].

To minimize the risk of microbial and other contamination of hospital HCW during various clinical procedures and examination procedures, hospital protective equipment are re-enforced with nanomaterials-antimicrobial agents that have been developed. Some of the HCW antimicrobial protective materials include surgical mask, gloves and many other latex personal protective equipment (PPE). For example, mixtures of silver nitrate and titanium dioxide NP coated on hospital facemask used during very delicate clinical procedures have shown to have significant protection against infectious agents [91, 93, 94]. The use of NPsantiseptics has also led to an increase in surface area to volume ratio, thus improving the lethal action of NPs-antiseptics against pathogens [91, 93].

As a result of the biocidal action and non-toxic nature of some NPs such as AgNPs, they are widely coated on medical devices to reduce infections [95]. In addition, nanomaterials of silver are being used in pet-animal shampoos as disinfection, cleaning and softening agents [96]. The AgNPs can also be coated on filters used for the purification of water. In some studies, PVK and SWNTs were found to destroy bacterial cell membranes [34].

Furthermore, NPs are currently being used as preservatives in packages to prevent food spoilage. For example, allyl isothiocyanate (AIT) and CNTs can be incorporated into packaging materials so as to prevent the contamination of food by Salmonella choleraesuis [97]. The allyl isothiocyanate (AIT) and CNTs work by providing an antimicrobial film that reduces the microbial contamination, control oxidation and reduces the colour changes for up to 40 days [97].

\section{Nanoparticles antimicrobial mechanisms of action}

Traditionally, most antimicrobial agents inhibit microbial growth through several mechanisms such as cell wall inhibition and lysis, inhibition of protein synthesis, alteration of cell membranes, inhibition of nucleic acid (NA) synthesis and antimetabolite activity [113]. The NP-antimicrobials, on the other hand, may encompass and differ slightly due to their vast physiochemical properties with respect to size, shape, surface area, surface energy, charge, crystallinity, agglomeration, aggregation and chemical composition [114-116]. Although most NP-antimicrobial mechanisms of action are still unknown and are currently under investigations [117], studies show that NPs can mediate bacterial cell membranes degradation [118-120]. For example, Li et al. [120] found the degradation of S. aureus by Catechin-Cu NPs. The Catechin-Cu NPs was also found to exert different mechanisms of action during $E$. coli cell wall degradation, which is an indication of different impacts on the Gram negative and Gram positive bacteria [120]. The multiple effects have also been observed in $\mathrm{CuNP}$-antimicrobial actions which include the generation of reactive oxygen species and lipid peroxidation [118]. Other CuNP-antibacterial actions include protein oxidation and DNA degradation in E. coli cells [118]. Another study by Xie et al. [121] showed that zinc oxide $(\mathrm{ZnO}) \mathrm{NPs}$ exerted bactericidal effect by disruption of the cell membrane and oxidative stress in Campylobacter jejuni. The NP-antimicrobials such as AgNP have also been shown to bind to lippopolysaccharides, surface proteins or porin, collapsing the microbial cell wall and limiting the membrane potential [122]. Similarly, AgNP have been found to induce efflux of phosphate, reduction of cellular ATP level, interacting with sulphahydryl (or thiol) group and altering cytoplasmic components as well as inhibiting the respiratory enzymes and blocking of DNA replication in both Gram negative and Gram positive bacterial pathogens [122]. These studies show that different NPs have very different physiochemical properties and thus exhibit different antimicrobial mechanisms of action.

\section{Nanoparticles toxicity}

The NPs antimicrobial agents have excellent potent and low tendency of inducing resistance when compared to non-NPs-antimicrobial agents [123]. However, the NP-antimicrobial agents' pharmacological properties may be hampered by potential toxicity $[123,124]$. As stated in previous sections of this review paper, NPs facilitate the penetration and delivery of antimicrobial agents into biological membranes including microbial cells, thereby enhancing and increasing biological activities [76, 113]. This means that the toxicity of different NP-antimicrobial polymers needs a timedependent understanding and characterization [125]. Generally, antimicrobial agents' biocompatibility inhibition cannot occur without producing some undesirable health effects, either local or systemic. In fact, the most deterring effect of most drugs is their potential toxicity to organisms of which NPs-antimicrobials agents are not an exception. Therefore, effective NP-antimicrobial agents' dose-related response is an important factor in relation to human exposure and other organisms. Few studies have described the toxicity of NP-antimicrobials (Table 1) with controversies. For example, a study by Cooper and Spitzer [126] shows that AgNPs antimicrobials at sub-lethal dose disrupt cytoskeleton and neurite dynamics when cultured in adult neural stem cells. For example, at sub-lethal dose of $1.0 \mu \mathrm{g} / \mathrm{mL}$, AgNP cultured in neural stem cells induced the formation of $\mathrm{f}$-actin inclusions, indicating a disruption of actin function [126]. Similar findings were reported by 
Baram-Pinto [101] that AgNPs capped with Mercaptoethane Sulfonate showed some serious effects in mammalian cells. Some results showed that PVK-SWCNTantimicrobial agents were nontoxic to fibroblast cells as opposed to pure SWCNTs [34]. Multivalent Sialic acid functionalized AuNPs-antimicrobials agents have also been shown to demonstrate no toxic effect on MadinDarby canine kidney cells [107]. Similarly, copper (II) nanohybrid solids-antimicrobial have shown no toxic effect on human hepatocellular carcinoma cells [109]. In another study, no cytotoxicity was reported when rats were treated with antibacterial AgNP-loaded titanium nanotube [127]. The rat cells expressed no toxicity thus demonstrating the competence of NPs-antimicrobials as future antimicrobial agents. However, despite several studies, the current available information is insufficient to ascertain the adverse effects of NP-antimicrobials on human health. Therefore, it is imperative that further research is carried out to mitigate any toxicological problems that may arise.

\section{Summary and future perspectives}

Research has shown that the functionalizationimmobilization and/or hybridization of NPs can enhance and improve the antimicrobial activities of the nanomaterials against a wide range of multi-resistant strains of pathogenic microorganisms. For example, a single type of NP-antimicrobial agent could show multiple antimicrobial properties against many pathogens. However, these characteristics may also alter the microbial flora of the body since their antimicrobial action is non-specific. Most of the studies reviewed showed that AgNPs were the widely used and have several antibacterial, antiviral, antifungal, anti-parasite, anti-insect and anti-vector borne properties. Generally, most NPantimicrobial drugs were able to target and transit difficult membrane barriers, deliver and sustain the NPantimicrobial doses resulting in disease clearance which is a difficult phenomenon for conventional antimicrobials. However, more information on the toxicological effects of $\mathrm{NP}$-antimicrobial agents is needed so as to enhance and broaden their biomedical application [76]. In some instances, depending on the size of the NP, the particle tended to be toxic rather than demonstrating antimicrobial effect of inhibiting pathogens. For example, very small AgNPs were found to cover the pathogen, inhibiting oxygen supply to the pathogen thus reducing respiration and toxically killing the pathogen rather than inhibiting the microbial growth [14]. However, very small NPs may also be toxic to human pathogens. For example, AgNPs ranging from $10-20 \mathrm{~nm}$ were found to be toxic to Bacillus species, E. coli and Staphylococcus species. [14]. Therefore, it is imperative that further research is carried out to mitigate such problems.
Competing interest

The authors declare that they have no competing interests.

\section{Authors' contributions}

CSY conceived, CSY and GSS collected and CSY drafted the manuscript. CSY and GSS analysed the data and additional information. Both authors have read and approved the final manuscript.

\section{Acknowledgements}

We acknowledge the Social Aspects for HIV/AIDS Research Alliance (SAHARA) unit of the HIV/AIDS, STIS and TB (HAST) at the Human Sciences Research Council (HSRC) of South Africa for providing conducive infrastructural environment during the course of the sourcing and writing of the manuscript.

\section{Disclaimer}

The contents of this paper reflect authors views who are responsible for the accuracy of the information presented herein. This paper does not constitute a standard, specification, nor is it intended for design, construction, bidding, or permit purposes.

\section{Author details}

'Department of Biochemistry and Microbiology, Nelson Mandela Metropolitan University, Port Elizabeth, South Africa. ${ }^{2}$ Department of Epidemiology, Johns Hopkins Bloomberg School of Public Health, E7146, 615 N. Wolfe Street, Baltimore 21205, MD, USA. ${ }^{3}$ School of Chemical and Metallurgical Engineering, University of the Witwatersrand, P/Bag 3, Wits 2050, Johannesburg, South Africa.

Received: 8 June 2015 Accepted: 12 August 2015

Published online: 02 September 2015

\section{References}

1. Galdiero S, Falanga A, Vitiello M, Cantisani M, Marra V, Galdiero M. Silver nanoparticles as potential antiviral agents. Molecules. 2011;16:8894-918.

2. Tanwar J, Das S, Fatima Z, Hameed S. Multidrug resistance: an emerging crisis. Interdiscip Perspect Infect Dis. 2014;2014:541340. 7 pages.

3. Sharma RK, Ghose R. Synthesis of zinc oxide nanoparticles by homogeneous precipitation method and its application in antifungal activity against Candida albicans. Ceram Int. 2015;141:967-75.

4. McCoy ME, Golden HE, Doll TA, Yang Y, Kaba SA, Zou X, et al. Mechanisms of protective immune responses induced by the Plasmodium falciparum circumsporozoite protein-based, self-assembling protein nanoparticle vaccine. Malar J. 2013;22:2-136.

5. Ngoy JM, lyuke SE, Neuse WE, Yah CS. Covalent functionalization for multi-walled carbon nanotube (f-MWCNT) -folic acid bound bioconjugate. J Appl Sci. 2011;11(15):2700-11.

6. Gilbertson LM, Goodwin DG, Taylor AD, Pfefferle L, Zimmerman JB. Toward tailored functional design of Multi-Walled Carbon Nanotubes (MWNTs): electrochemical and antimicrobial activity enhancement via oxidation and selective reduction. Environ Sci Technol. 2014;48:5938-45.

7. Parise A, Thakor H, Zhang X. Activity inhibition on municipal activated sludge by single-walled carbon nanotubes. J Nanoparticle Res. 2014;16:2159.

8. Qi X, Gunawan P, Xu R, Chang MW. Cefalexin-immobilized multi-walled carbon nanotubes show strong antimicrobial and anti-adhesion properties. Chem Eng Sci. 2015;84:552-6.

9. Venkatesan J, Jayakumar R, Mohandas A, Bhatnagar I, Kim SK. Antimicrobial activity of chitosan-carbon nanotube hydrogels. Materials. 2014;7:3946-55.

10. Adeli M, Hosainzadegan H, Pakzad I, Zabihi F, Alizadeh M, Karimi F. Preparation of the silver nanoparticle containing starch foods and evaluation of antimicrobial activity. Jundishapur J Microbiol. 2013;6(4):e5075.

11. Subbiah R, Veerapandian M, Sadhasivam S, Yun K. Triad CNT-NPs/Polymer nanocomposites: fabrication, characterization, and preliminary antimicrobial study. Synth React Inorg Met-Org Nano-Met Chem. 2011;41:345-55.

12. Addae E, Dong X, McCoy E, Yang C, Chen W, Yang L. Investigation of antimicrobial activity of photothermal therapeutic gold/copper sulphide core/shell nanoparticles to bacterial spores and cells. J Biol Eng. 2014;8:11.

13. Sui M, Zhang L, Sheng L, Huang S, She L. Synthesis of ZnO coated multi-walled carbon nanotubes and their antibacterial activities. Sci Total Environ. 2013;452-453:148-54. 
14. Sunitha A, Rimal IRS, Sweetly G, Sornalekshmi S, Arsula R, Praseetha PK. Evaluation of antimicrobial activity of biosynthesized iron and silver Nanoparticles using the fungi Fusarium oxysporum and Actinomycetes sp. on human pathogens. Nano Biomed Eng. 2013;5(1):39-45.

15. Hoffmann H-H, Kunz A, Simon VA, Palese P, Shawa ML. Broad-spectrum antiviral that interferes with de novo pyrimidine biosynthesis. Proc Natl Acad Sci U S A. 2011;108(14):5777-82.

16. Kollef $\mathrm{MH}$. Broad-spectrum antimicrobials and the treatment of serious bacterial infections: Getting It Right Up Front. Clin Infect Dis. 2008:47(Supplement 1):S3-13.

17. Kwon DS, Mylonakis E. Posaconazole: a new broad-spectrum antifungal agent. Expert Opin Pharmacother. 2007;8(8):1167-78

18. Navarrete-Vazquez G, Chávez-Silva F, Argotte-Ramos R, Rodríguez-Gutiérrez Mdel C, Chan-Bacab MJ, Cedillo-Rivera R, et al. Synthesis of benzologues of Nitazoxanide and Tizoxanide: a comparative study of their in vitro broad-spectrum antiprotozoal activity. Bioorg Med Chem Lett. 2011;21(10):3168-71.

19. Rupp R, Rosenthal SL, Stanberry LR. VivaGel ${ }^{T M}$ (SPL7013 Gel): A candidate dendrimer -microbicide for the prevention of HIV and HSV infection. Int J Nanomedicine. 2007;2(4):561-6.

20. Marambio-Jones C, Hoek EMV. A review of the antibacterial effects of silver nanomaterials and potential implications for human health and the environment. J Nanoparticle Res. 2010;12:1531-51.

21. San CY, Don MM. Biosynthesis of silver nanoparticles from Schizophyllum Communeand in-vitro antibacterial and antifungal activity studies. J Phys Sci. 2013;24(2):83-96.

22. Kathiravan V, Ravi S, Ashokkumar S, Velmurugan S, Elumalai K, Khatiwada CP. Green synthesis of silver nanoparticles using Croton sparsiflorus morong leaf extract and their antibacterial and antifungal activities. Spectrochim Acta A Mol Biomol Spectrosc. 2015;139:200-5.

23. Gaikwad S, Ingle A, Gade N, Rai M, Falanga A, Incoronato N, et al. Antiviral activity of mycosynthesized silver nanoparticles against herpes simplex virus and human parainfluenza virus type 3. Int J Nanomedicine. 2013;8:4303-14.

24. Elmi T, Gholami S, Fakhar M, Azizi F. A review on the use of nanoparticles in the treatment of parasitic infections. J Mazand Uni Med Sci. 2013;23:127-34.

25. Fayaz AM, Ao Z, Girilal M, Chen L, Xiao X, Kalaichelvan P, et al. Inactivation of microbial infectiousness by silver nanoparticles-coated condom: a new approach to inhibit HIV- and HSV-transmitted infection. Int J Nanomedicine. 2012;7:5007-18

26. Tank C, Raman S, Karan S, Gosavi S, Lalla NP, Sathe V, et al. Antimicrobial activity of silica coated silicon nano-tubes (SCSNT) and silica coated silicon nano-particles (SCSNP) synthesized by gas phase condensation. J Mater Sci Mater Med. 2013;24(6):1483-90.

27. Zhou J, Qi X. Multi-walled carbon nanotubes/epilson-polylysine nanocomposite with enhanced antibacterial activity. Lett Appl Microbiol. 2010;52:76-83

28. Aslan S, Deneufchatel M, Hashmi S, Li N, Pfefferle LD, Elimelech M, et al. Carbon nanotube-based antimicrobial biomaterials formed via layer-by-layer assembly with polypeptides. J Colloid Interface Sci. 2012;388(1):268-73.

29. Amiri A, Zardini HZ, Shanbedi M, Maghrebi M, Baniadam M, Tolueinia BB Efficient method for functionalization of carbon nanotubes by lysine and improved antimicrobial activity and water-dispersion. Mater Lett. 2012;72:153-6.

30. Barbinta-Patrascu ME, Ungureanu C, lordache SM, lordache AM, Bunghez IR, Ghiurea $\mathrm{M}$, et al. Eco-designed biohybrids based on liposomes, mintnanosilver and carbon nanotubes for antioxidant and antimicrobial coating. Mater Sci Eng C Mater Biol Appl. 2014;39:177-85.

31. Neelgund GM, Oki A, Luo Z. Antimicrobial activity of CdS and Ag2S quantum dots immobilized on poly(amidoamine) grafted carbon nanotubes. Colloids Surf B Biointerfaces. 2012;100:215-21.

32. Geraldo DA, Arancibia-Miranda N, Villagra NA, Mora GC, Arratia-Perez R. Synthesis of CdTe QDs/single-walled aluminosilicate nanotubes hybrid compound and their antimicrobial activity on bacteria. J Nanoparticle Res. 2012;14:1286.

33. Booshehri AY, Wang R, Xu R. The effect of re-generable silver nanoparticles/ multi-walled carbon nanotubes coating on the antibacterial performance of hollow fibermembrane. Chem Eng J. 2013:230:251-9.

34. Ahmed F, Santos CM, Mangadlao J, Advincula R, Rodrigues DF. Antimicrobial PVK:SWNT nanocomposite coated membrane for water purification: Performance and toxicity testing. Water Res. 2013;47:3966-75.

35. Santos-Magalhães NS, Mosqueira VC. Nanotechnology applied to the treatment of malaria. Adv Drug Deliv Rev. 2010;62(4-5):560-75.
36. Said DE, ElSamad LM, Gohar YM. Validity of silver, chitosan, and curcumin nanoparticles as anti-Giardia agents. Parasitol Res. 2012;111(2):545-54.

37. Allahverdiyev AM, Abamor ES, Bagirova M, Ustundag CB, Kaya C, Kaya F, et al. Antileishmanial effect of silver nanoparticles and their enhanced antiparasitic activity under ultraviolet light. Int J Nanomedicine. 2011;6:2705-14.

38. Das S, Bhattacharya A, Debnath N, Datta A, Goswami A. Nanoparticleinduced morphological transition of Bombyx mori nucleopolyhedrovirus: a novel method to treat silkworm grasserie disease. Appl Microbiol Biotechnol. 2013;97(13):6019-30.

39. Veerakumar K, Govindarajan M, Hoti SL. Evaluation of plant-mediated synthesized silver nanoparticles against vector mosquitoes. Parasitol Res. 2014:113:4567-77.

40. Poopathi S, De Britto LJ, Praba VL, Mani C, Praveen M. Synthesis of silver nanoparticles from Azadirachta indica - a most effective method for mosquito control. Environ Sci Pollut Res. 2015;22:2956-63.

41. Soni N, Prakash S. Efficacy of fungus mediated silver and gold nanoparticles against Aedes aegypti larvae. Parasitol Res. 2012;110:175-84

42. Kramer MF, Cook WJ, Roth FP, Zhu J, Holman H, Knipe DM, et al. Latent herpes simplex virus infection of sensory neurons alters neuronal gene expression. J Virol. 2003;77(17):9533-41.

43. Sharman D. Moist wound healing: a review of evidence, application and outcome - Review. Diabet Foot J. 2003:6(3):112-20.

44. Yah SC, Enabulelel O, Eghafona NO, Udemezue OO. Prevalence of Pseudomonas in burn wounds at the University of Benin teaching Hospital. Benin City, Nigeria. J Exp Clin Anat (JECA). 2004;3(1):12-5.

45. Hiro ME, Pierpont YN, Ko F, Wright TE, Robson MC, Payne WG. Comparative evaluation of silver containing antimicrobial dressing on the In-vitro and In vivo processing of wound healing. ePlasty. 2012;12:409-19.

46. Yah SC, Yusuf EO, Haruna T. Patterns of antibiotics susceptibility of isolates and plasmid analysis of Staphylococcus aureus from Postoperative Wound Infections. Int J Biol Chem Sci. 2009:3(4):810-8.

47. Jones V, Grey JE, Harding KG. Wound dressings. BMJ. 2006;332:777-80.

48. Stashak TS, Farstvedt E, Othica A. Update on wound dressings: Indications and best use. Clin Tech Equine Pract. 2004;3:148-63.

49. Kwan KH, Liu X, Yeung KW. Silver nanoparticles improve wound healing. Nanomedicine. 2011;6(4):595-6.

50. Caló E, Khutoryanskiy W. Biomedical applications of hydrogels: a review of patents and commercial products. Eur Polym J. 2015;65:252-67.

51. Guidelli EJ, Kinoshita A, Ramos AP, Baffa O. Silver nanoparticles delivery system based on natural rubber latex membranes. J Nanoparticle Res. 2013;15:1536.

52. Rigo C, Ferroni L, Tocco L, Roman M, Munivrana I, Gardin C, et al. Carlo Barbante 4 and Barbara ZavanActive silver nanoparticles for wound healing Int J Mol Sci. 2013:14:4817-40.

53. Tian J, Wong KK, Ho CM, Lok CN, Yu WY, Che CM, et al. Topical delivery of silver nanoparticles promotes wound healing. Chem Med Chem. 2007;2:129-36

54. John JS, Moro DG. Hydrogel wound dressing and biomaterials formed in situ and their uses. Patent US7910135 B2. 2011

55. Leu JG, Chen SA, Chen HM, Wu WM, Hung CF, Yao YD, et al. The effects of gold nanoparticles in wound healing with antioxidant epigallocatechin gallate and a-lipoic acid. Nanomedicine. 2012;8(5):767-75.

56. Krausz AE, Adler BL, Cabral V, Navati M, Doerner J, Charafeddine RA, et al. Curcumin-encapsulated nanoparticles as innovative antimicrobial and wound healing agent. Nanomedicine. 2015;11(1):195-206.

57. Madhumathi K, Kumar PTS, Abhilash S, Sreeja V, Tamura H, Manzoor K, et al. Development of novel chitin/nanosilver composite scaffolds for wound dressing applications. J Mater Sci Mater Med. 2010;21920:807-13.

58. Ziv-Polat O, Topaz M, Brosh T, Margel S. Enhancement of incisional wound healing by thrombin conjugated iron oxide nanoparticles. Biomaterials. 2010:31(4):741-7.

59. Mihu MR, Sandkovsky U, Han G, Friedman JM, Nosanchuk JD, Martinez LR. The use of nitric oxide releasing nanoparticles as a treatment against Acinetobacter baumannii in wound infections. Virulence. 2010;1(2):62-7.

60. Chonco L, Pion M, Vacas E, Rasines B, Maly M, Serramía MJ, et al. Carbosilane dendrimer nanotechnology outlines of the broad HIV blocker profile. J Control Release. 2012;161(3):949-58.

61. Fields S, Song B, Rasoul B, Fong J, Works MG, Shew K, et al. New candidate biomarkers in the female genital tract to evaluate microbicide toxicity. PLOS ONE. 2014;9(10):e110980. 
62. Gary AB, Nuttall J, Romano J. The future of HIV microbicides: challenges and opportunities. Antivir Chem Chemother. 2009;19:143-50.

63. Galea JT. Preparing for rectal microbicides: sociocultural factors affecting product uptake among potential South American users. Am J Public Health. 2014;104(6):e113-20.

64. Morris GC, Wiggins RC, Woodhall SC, Bland JM, Taylor CR, Jespers V, et al. MABGEL 1: first phase 1 trial of the anti-HIV-1 monoclonal antibodies 2F5, 4E10 and 2G12 as a vaginal microbicide. PLoS ONE. 2014;9(12):e116153.

65. Harper CC, Holt K, Nhemachena T, Chipato T, Ramjee G, Stratton L, et al. Willingness of clinicians to integrate microbicides into HIV prevention practices in southern Africa. AIDS Behav. 2012;16(7):1821-9.

66. McCarthy TD, Karellas P, Henderson SA, Giannis M, O'Keefe D F, Heery G, et al. Dendrimers as drugs: discovery and preclinical and clinical development of dendrimer-based microbicides for HIV and STI prevention. Mol Pharm. 2005;2:312-8

67. Gong E, Matthews B, McCarthy T, Chu J, Holan G, Raff J, et al. Evaluation of dendrimer SPL7013, a lead microbicide candidate against herpes simplex viruses. Antivir Res. 2005;68:139-46.

68. Donalisio M, Rusnati M, Cagno V, Civra A, Bugatti A, Giuliani A, et al. Inhibition of human respiratory syncytial virus infectivity by a dendrimeric heparan sulfate-binding peptide. Antimicrob Agents Chemother. 2012;56(10):5278-88.

69. Price CF, Tyssen D, Sonza S, Davie A, Evans S, Lewis G R, et al. SPL7013 Gel $\left(V_{i v a G e}{ }^{\oplus}\right)$ retains potent HIV-1 and HSV-2 inhibitory activity following vaginal administration in humans. PLoS ONE. 2011;6(9):e24095.

70. Imbuluzqueta E, Gamazo C, Ariza I, Blanco-Prieto MJ. Drug delivery systems for potential treatment of intracellular bacterial infections. Front Biosci (Landmark Ed). 2010;15:397-417.

71. Alizadeh H, Salouti M, Shapouri M. Bactericidal effect of silver nanoparticles on intramacrophage brucella abortus 544. Jundishapur J Microbiol. 2014;7:e9039.

72. Xie S, Tao Y, Pan Y, Qu W, Cheng G, Huang L, et al. Biodegradable nanoparticles for intracellular delivery of antimicrobial agents. J Control Release. 2014;187:101-17

73. Upadhyay RK. Drug delivery systems, CNS protection, and the blood brain barrier. Biomed Res Int. 2014;2014:869269. 37 pages.

74. Zhang L, Pornpattananangkul D, Hu CMJ, Huang CM. Development of nanoparticles for antimicrobial drug delivery. Curr Med Chem. 2010;17:585-94.

75. Yah CS, lyuke SE, Simate GS. Nanoparticles toxicity and their routes of exposures. Pak J Pham Sci. 2012;25(2):477-91.

76. Simate GS, Yah CS. The use of carbon nanotubes in medical applications - is it a success story? Occup Med Health Aff. 2014;2(1):147.

77. Welin A. Survival strategies of Mycobacterium tuberculosis inside the human macrophage. Linköping University Medical Dissertations. Sweden Linköping University: Division of Medical Microbiology Department of Clinical and Experimental Medicine, Faculty of Health Sciences Linköping University SE-58185 Linköping; 2011.

78. Kumar KR, Nattuthurai N, Gopinath P, Mariappan T. Synthesis of eco-friendly silver nanoparticles from Morinda tinctoria leaf extract and its larvicidal activity against Culex quinquefasciatus. Parasitol Res. 2015;114:411-7.

79. Malone FD, Athanassiou A, Nores LA, Dalton ME. Poor perinatal outcome associated with maternal Brucella abortus infection. Obstet Gynecol. 1997;90(4 Pt 2):674-6.

80. Dong X, Tang Y, Wu M, Vlahovic B, Yang L. Dual effects of single-walled carbon nanotubes coupled with near-infrared radiation on Bacillus anthracis spores: inactivates spores and stimulates the germination of surviving spores. J Biol Eng. 2013;7:19.

81. Martinez-Gutierrez F, Thi EP, Silverman JM, de Oliveira CC, Svensson SL, Vanden Hoek A, et al. Antibacterial activity, inflammatory response, coagulation and cytotoxicity effects of silver nanoparticles. Nanomedicine. 2012;8(3):328-36

82. Briones $\mathrm{E}$, Colino $\mathrm{Cl}$, Lanao IM. Delivery systems to increase the selectivity of antibiotics in phagocytic cells. J Control Release. 2008;125:210-27.

83. Masserini M. Nanoparticles for brain drug delivery. ISRN Biochemistry. 2013;2013:238428. 18 pages.

84. Gandhi M, Bohra H, Daniel V, Gupta A. Nanotechnology in blood brain barrier. Int J Pharm Biol Arch. 2010;1(1):37-43.

85. Haque S, Md S, Alam MI, Sahni JK, AliN J, Baboota S. Nanostructure-based drug delivery systems for brain targeting. Drug Dev Ind Pharm. 2012;38(4):387-411.

86. Khuller GK, Pandey R. Oral nanoparticle-based antituberculosis drug delivery to the brain in an experimental model. J Antimicrob Chem. 2006;57:1146-52.
87. Lilly M, Dong X, McCoy E, Yang L. Inactivation of Bacillus anthracis spores by single-walled carbon nanotubes coupled with oxidizing antimicrobial chemicals. Environ Sci Technol. 2012;46(24):13417-24.

88. McDonnell G, Russell AD. Antiseptics and disinfectants: activity, action, and resistance. Clin Microbiol Rev. 1999;12(1):147-79.

89. Gutiérrez LG. Nanoparticulate titanium dioxide nanomaterial modified with functional groups and with citric extracts adsorbed on the surface, for the removal of a wide range of microorganisms. Patent. WO/2014/204290. 2010.

90. Vetten MV, Yah CS, Singh T, Gullumian M. Challenges facing sterilization and depyrogenation of nanoparticles: effects on structural stability and biomedical applications. Nanomedicine. 2014;10(7):1391-9.

91. Bouchard M, Bouchard J-M. Disinfectant cleaner. Patent no. US20110195131A1. 2011.

92. Turos E, Shim JY, Wang Y, Greenhalgh K, Reddy GS, Dickey S, et al. Antibiotic-conjugated polyacrylate nanoparticles: new opportunities for development of anti-MRSA agents. Bioorg Med Chem Lett. 2007;17(1):53-6.

93. Ismail S, Perni S, Pratten J, Parkin I, Wilson M. Efficacy of a novel light-activated antimicrobial coating for disinfecting hospital surfaces. Infect Control Hosp Epidemiol. 2011;32(11):1130-2.

94. Li Y, Leungb P, Yaoa L, Songa QW, Newtona E. Antimicrobial effect of surgical masks coated with nanoparticles. J Hosp Infect. 2006;62(1):58-63.

95. Reiche T, Lisby G, Jorgensen S, Christensen A B, Nordling J. A prospective, controlled, randomized study of the effect of a slow-release silver device on the frequency of urinary tract infection in newly catheterized patients. BJU Int. 2000:85:54-9.

96. Troncarelli MZ, Brandão HM, Gern JC, Guimarães AS, Langoni H. Nanotechnology and antimicrobials in veterinary medicine. Badajoz, Spain: FORMATEX; 2013.

97. Dias MV, Soares Nde F, Borges SV, de Sousa MM, Nunes CA, de Oliveira IR, et al. Use of allyl isothiocyanate and carbon nanotubes in an antimicrobial film to package shredded, cooked chicken meat. Food Chem. 2013;141(3):3160-6.

98. Ajitha B, Reddy YAK, Reddy PS. Biosynthesis of silver nanoparticles using Plectranthus amboinicus leaf extract and its antimicrobial activity. Spectrochim Acta A Mol Biomol Spectrosc. 2014;128:257-62.

99. Sun RW, Chen $\mathrm{R}$, Chung NP, Ho CM, Lin CL, Che CM. Silver nanoparticles fabricated in Hepes buffer exhibit cytoprotective activities toward HIV-1 infected cells. Chem Commun (Camb). 2005:40:5059-61.

100. Lara HH, Nilda V, Ayala-Nuñez NV, Ixtepan-Turrent L, Rodriguez-Padilla C. Mode of antiviral action of silver nanoparticles against HIV-1. J Nanobiotechnol. 2010;8:1.

101. Baram-Pinto D, Shukla S, Perkas N, Gedanken A, Sarid R. Inhibition of herpes simplex virus type 1 infection by silver nanoparticles capped with mercaptoethane sulfonate. Bioconjug Chem. 2009;20:1497-502.

102. Sun L, Singh AK, Vig K, Pillai S, Shreekumar R, Singh SR. Silver nanoparticles inhibit replication of respiratory sincitial virus. J Biomed Biotechnol. 2008;4:149-58.

103. Rogers JV, Parkinson CV, Choi YW, Speshock JL, Hussain SM. A preliminary assessment of silver nanoparticles inhibition of monkeypox virus plaque formation. Nanoscale Res Lett. 2008;3:129-33.

104. Liu X, Yu L, Liu F, Sheng L, An K, Chen H, et al. Preparation of Ag-Fedecorated single-walled carbon nanotubes by arc discharge and their antibacterial effect. J Mater Sci. 2012;47:6086-94.

105. Speshock JL, Murdock RC, Braydich-Stolle LK, Schrand AM, Hussain SM. Interaction of silver nanoparticles with Tacaribe virus. J Nanobiotechnol. 2010;8:19-27.

106. Banu AN, Balasubramanian C, Vinayaga MP. Biosynthesis of silver nanoparticles using Bacillus thuringiensis against dengue vector, Aedes aegypti (Diptera: Culicidae). Parasitol Res. 2014;113:311-6.

107. Papp I, Sieben C, Ludwig K, Roskamp M, Böttcher C, Schlecht S, et al. Inhibition of influenza virus infection by multivalent sialic-acidfunctionalized gold nanoparticles. Small. 2010;6:2900-6.

108. Marimuthu S, Rahuman AA, Kirthi AV, Santhoshkumar T, Jayaseelan C, Rajakumar G. Eco-friendly microbial route to synthesize cobalt nanoparticles using Bacillus thuringiensis against malaria and dengue vectors. Parasitol Res. 2013;112(12):4105-12.

109. Mohapatra SC, Tiwari HK, Singla M, Rathi B, Sharma A, Mahiya K, et al. Antimalarial evaluation of copper(II) nanohybrid solids: inhibition of plasmepsin II, a hemoglobin-degrading malarial aspartic protease from Plasmodium falciparum. J Biol Inorg Chem. 2010;15(3):373-85.

110. Kirthi AV, Rahuman A, Rajakumar G, Marimuthu S, Santhoshkumar T, Jayaseelan C, et al. Acaricidal, pediculocidal and larvicidal activity of 
synthesized ZnO nanoparticles using wet chemical route against blood feeding parasites. Parasitol Res. 2011;109:461-72.

111. Gowri S, Gandhi RR, Sundrarajan M. Structural, optical, antibacterial and antifungal properties of zirconia nanoparticles by biobased protocol. J Mater Sci Technol. 2014;30(8):782e790.

112. Lu L, Sun RW, Chen R, Hui CK, Ho CM, Luk JM, et al. Silver nanoparticles inhibit hepatitis B virus replication. Antivir Ther. 2008;13:253-62.

113. Pelczar M, Reid R, Chan ECS. Microbiologia. São Paulo: McGraw-Hill; 1980 p. 2008.

114. Senior K, Müller S, Schacht VJ, Bunge M. Antimicrobial precious-metal nanoparticles and their use in novel materials. Recent Pat Food Nutr Agric. 2012:4(3):200-9.

115. Yah CS. The toxicity of gold nanoparticles in relation to their physiochemical properties. Biomed Res. 2013;24(3):400-13.

116. Gatoo MA, Naseem S, Arfat MY, Dar AM, Qasim K, Zubair S. Physicochemical properties of nanomaterials: implication in associated toxic manifestations. Biomed Res Int. 2014;2014:498420.

117. Dorotkiewicz-Jach A, Augustyniak D, Olszak T, Drulis-Kawa Z. Modern therapeutic approaches against pseudomonas aeruginosa infections. Curr Med Chem. 2015;22(14):1642-64.

118. Chatterjee AK, Chakraborty R, Basu T. Mechanism of antibacterial activity of copper nanoparticles. Nanotechnology. 2014;25(13):135101.

119. Dong Q, Dong A, Morigen. Evaluation of novel antibacterial N-halamine nanoparticles prodrugs towards susceptibility of escherichia coli induced by DksA protein. Molecules. 2015;20(4):7292-308.

120. Li H, Chen Q, Zhao J, Urmila K. Enhancing the antimicrobial activity of natural extraction using the synthetic ultrasmall metal nanoparticles. Sci Rep. 2015:5:11033.

121. Xie $Y$, He Y, Irwin PL, Jin T, Shi X. Antibacterial activity and mechanism of action of zinc oxide nanoparticles against Campylobacter jejuni. Appl Environ Microbiol. 2011;77(7):2325-31.

122. Bawskar M, Deshmukh S, Bansod S, Gade A, Rai M. Comparative analysis of biosynthesised and chemosynthesised silver nanoparticles with special reference to their antibacterial activity against pathogens. IET Nanobiotechnol. 2015;9(3):107-13.

123. Piras AM, Maisetta G, Sandreschi S, Gazzarri M, Bartoli C, Grassi L, et al. Chitosan nanoparticles loaded with the antimicrobial peptide temporin $\mathrm{B}$ exert a long-term antibacterial activity in vitro against clinical isolates of Staphylococcus epidermidis. Front Microbiol. 2015;6:372.

124. Mogharabi M, Abdolahi M, Faramarzi MM. Toxicity of nanomaterials. Daru. 2014;22:9.

125. Nuñez-Anita RE, Acosta-Torres LS, Vilar-Pineda J, Martínez-Espinosa JC, de la Fuente-Hernández J, Castaño VM. Toxicology of antimicrobial nanoparticles for prosthetic devices. Int J Nanomedicine. 2014;9:3999-4006.

126. Cooper RJ, Spitzer N. Silver nanoparticles at sublethal concentrations disrupt cytoskeleton and neurite dynamics in cultured adult neural stem cells. Neurotoxicology. 2015;48:231-8.

127. Uhm SH, Lee SB, Song DH, Kwon JS, Han JG, Kim KN. Fabrication of bioactive, antibacterial TiO2 nanotube surfaces, coated with magnetron sputtered Ag nanostructures for dental applications. J Nanosci Nanotechnol. 2014; 14(10):7847-54

\section{Submit your next manuscript to BioMed Central and take full advantage of:}

- Convenient online submission

- Thorough peer review

- No space constraints or color figure charges

- Immediate publication on acceptance

- Inclusion in PubMed, CAS, Scopus and Google Scholar

- Research which is freely available for redistribution 